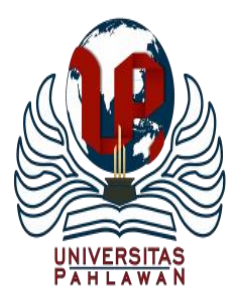

Jurnal Abdidas Volume 1 Nomor 5 Tahun 2020 Halaman 363 - 372

JURNAL ABDIDAS

Community Development Service on Educational and Health Sciences

http://abdidas.org/index.php/abdidas

\title{
Penyuluhan Perilaku Hidup Sehat dan Bersih (PHBS) dan Gerakan Masyarakat Hidup Sehat (GERMAS) kepada Lanjut Usia (LANSIA) Menghadapi Masa Pandemi Covid 19 dan New Normal dengan Metode 3M
}

\author{
Herniwanti ${ }^{1}$, Octavia Dewi ${ }^{2}$, Jasrida Yunita ${ }^{3}$, Endang Purnawati Rahayu ${ }^{4}$ \\ STIKes Hang Tuah Pekanbaru ${ }^{1,2,3,4}$ \\ E-mail : herniwanti_h@yahoo.com ${ }^{1}$ dewitavia@yahoo.com² ${ }^{2}$ jasridayunita@gmail.com ${ }^{3}$ \\ endangpurnawati90@gmail.com ${ }^{4}$
}

\begin{abstract}
Abstrak
Lansia merupakan suatu kelompok penduduk yang cukup rentan dan terdampak dalam masalah kesehatan dan psikologis di era pandemi COVID 19 (new normal). Salah satu usaha dari pemerintah dalam menjaga lansia agar tidak terpapar wabah ini adalah dengan promosi kesehatan di Posyandu Lansia. Tujuan dari kegiatan adalah penyuluhan PHBS dan GESMAS (Gerakan Masyarakat Hidup Sehat) yang merupakan bagian dari promosi kesehatan dalam bidang kesehatan lingkungan dalam mendukung pemutusan rantai penyebaran COVID 19 dan siap menghadapi masa new normal. Metode Kegiatan Pengadian Masyarakat bekerjasama dengan kader lansia dan dosen Magister Ilmu Kesehatan Masyarakat Stikes Hang Tuah pekanbaru di Posyandu Lansia Sapta Tarunia di Kec. Bukit Raya - Kota. Rangkaian acara yaitu pemeriksaan kesehatan, pembagian masker, peragaan cuci tangan pakai sabun, pemberian makanan sehat tambahan dan souvenir alat kebersihan, diskusi, observas dan evaluasi. Program PHBS dan GERMAS disosialisasikan kepada lansia dengan memasang poster di posyandu lansia sehingga bisa dilihat setiap saat. Kehadiran lansia di posyandu perlu ditingkatkan dengan bantuan keluarga dan lingkungan serta promosi kesehatan dimasa yang menarik dan inovasi.
\end{abstract}

Kata kunci: lansia, PHBS, GERMAS, COVID 19, new normal, metode 3M

\section{Abstract}

The elderly are a population group that is quite vulnerable and affected by health and psychological problems in the era of the Covid 19 pandemic (new normal). One of the efforts of the government to protect the elderly from being exposed to this problem is by promoting health at the elderly Posyandu.The objective of the activity is to provide education on PHBS and GESMAS (Healthy Living Community Movement) which is part of health promotion in the field of environmental health in supporting breaking the chain of the spread of Covid 19 and ready to face the new normal period.Methods of Community Service Activities in collaboration with elderly cadres and master lecturers of public health science at Stikes Hang Tuah Pekanbaru at the Sapta Tarunia Elderly Posyandu in Kec. Bukit Raya - Pekanbaru City. Series of events: health checks, distribution of masks, demonstration of washing hands with soap, providing additional healthy food and hygiene souvenirs, discussion, observation and evaluation. The PHBS and GERMAS programs are socialized to the elderly by putting up posters at the posyandu for the elderly so they can be seen at any time. The presence of the elderly at posyandu needs to be increased with the help of family and the environment as well as health promotion in an interesting and innovative time

Keywords: elderly, PHBS, GERMAS, COVID 19, new normal, 3M method.

Copyright (c) 2020 Herniwanti, Octavia Dewi, Jasrida Yunita, Endang Purnawati Rahayu

$\checkmark$ Corresponding author

Address : Jln.Paus Ujung No.5, Marpoyan Damai Pekanbaru

Email : Herniwanti_h@yahoo.com

Phone : 082156553120

ISSN 2721- 9224 (Media Cetak)

DOI : https://doi.org/10.31004/abdidas.v1i5.82

ISSN 2721- 9216 (Media Online)

Jurnal Abdidas Vol 1 No 5 Tahun 2020 p-ISSN 2721-9224 e-ISSN 2721-9216 

dengan Metode 3M - Herniwanti, Octavia Dewi, Jasrida Yunita, Endang Purnawati Rahayu

DOI : https://doi.org/10.31004/abdidas.v1i5.82

\section{PENDAHULUAN}

Posyandu lansia merupakan pos pelayanan terpadu terhadap lansia di tingkat desa/kelurahan dalam wilayah kerja masing-masing puskesmas. Adapun tujuan dari pembentukan posyandu lansia yaitu meningkatkan derajat kesehatan dan mutu pelayanan kesehatan usia lanjut di masyarakat, untuk mencapai masa tua yang bahagia dan berdaya guna bagi keluarga, dan meningkatkan peran serta masyarakat dalam pelayanan kesehatan dan komunikasi antara masyarakat (Juniardi, 2013).

Jumlah penduduk lansia di Indonesia telah meningkat dan kesehatan lansia masih rendah, pemerintah mengadakan program khusus yaitu Posyandu Lansia di daerah tertentu yang telah disepakati, yang digerakkan oleh masyarakat di mana mereka bisa mendapatkan pelayanan kesehatan. Namun, frekuensi kunjungan lansia ke posyandu di beberapa posyandu masih rendah dengan rata-rata kunjungan yaitu 41,76\%. Hal ini masih jauh dari target yang telah di tetapkan oleh Dinas Kesehatan yaitu 80\%. Posyandu Lansia merupakan wahana pelayanan bagi kaum usia lanjut, yang dilakukan dari, oleh ,dan untuk kaum usila yang menitikberatkan pada pelayanan promotif dan preventif, tanpa mengabaikan upaya kuratif dan rehabilitatif, kegiatannya adalah pemeriksaan kesehatan secara berkala, peningkatan olahraga, pengembangan keterampilan, bimbingan pendalaman agama, dan pengelolaan dana sehat (Arpan \& Sunarti, 2017).
Salah satu usaha dari pemerintah dalam meningkatkan kualitas hidup lansia dan meningkatkan derajat kesehatan di Indonesia adalah dengan cara membentuk Posyandu Lansia. Posyandu Lansia merupakan program puskesmas melalui kegiatan peran serta masyarakat setempat, khususnya lansia. Pelayanan kesehatan di Posyandu Lansia meliputi pemeriksaan kesehatan fisik, mental, emosional yang dicatat dan dipantau dengan kartu menuju sehat (KMS) untuk mengetahui lebih awal penyakit yang di derita atau ancaman salah satu kesehatan yang dihadapi (Herman, 2011).

\section{Perilaku Hidup Sehat Dan Bersih (PHBS)}

serta Gerakan Masyarakat Hidup Sehat (GERMAS) pada lanjut usia dipengaruhi oleh faktor keadaan masa lalu, situasi lingkungan, keluarga serta faktor-faktor pribadi. Lansia perlu mendapatkan perhatian dengan mengupayakan agar mereka tidak terlalu tergantung kepada orang lain dan mampu mengurus diri sendiri (mandiri), menjaga kesehatan diri (Kauman et al., 2019).

Pelaksanaan upaya promotif yang bertujuan untuk menumbuhkan kesadaran masyarakat dan mengubah perilaku yang meliputi aspek pengetahuan, sikap, dan tindakan sehingga terwujud perubahan perilaku hidup sehat yang benar karena sebagian dari Lansia masih kurang dalam penerapan PHBS yang baik (Putri, 2019).

Untuk meningkatkan pengetahuan dapat dilakukan dengan promosi kesehatan tentang Perilaku Hidup Bersih dan Sehat. Promosi kesehatan memberikan pengaruh terhadap 

dengan Metode 3M - Herniwanti, Octavia Dewi, Jasrida Yunita, Endang Purnawati Rahayu

DOI : https://doi.org/10.31004/abdidas.v1i5.82

pengetahuan dan sikap PHBS (Kurniawan et al., 2019). Promosi kesehatan PHBS memberikan pengaruh terhadap pengetahuan dan sikap (R Roni, S Susmini, 2018).

Berdasarkan observasi awal yang dilakukan bahwa kondisi lanjut usia Posyandu Lansia Puskesmas Sapta Taruna Kec. Bukit Raya-Kota Pekanbaru setiap dua kali dalam sebulan ada kegiatan di Posyandu Lansia agar lansia selalu dalam kondisi sehat. Dengan ini, maka perlu dilaksanakan peningkatan pengetahuan dan pencegahan kesehatan lanjut yang diharapkan dapat membantu dan memberi manfaat bagi masyarakat.

Penyuluhan Perilaku Hidup Sehat Dan Bersih (PHBS) serta Gerakan Masyarakat Hidup Sehat (GERMAS) pada lanjut usia di Posyandu Lansia Puskesmas Sapta Taruna Kec. Bukit RayaKota Pekanbaru bertujuan untuk memberikan pengetahuan dan sosialisasi serta manfaat dari kegiatan ini dapat menambah wawasan kesehatan lingkungan kepada masyarakat pada umumnya dan lansia khususnya mengenai Perilaku Hidup Sehat Dan Bersih (PHBS) serta Gerakan Masyarakat Hidup Sehat (GERMAS).

\section{METODE}

Kegiatan pengabdian kepada masyarakat ini dilaksanakan dengan bekerjasama dengan Puskesmas Sapta Taruna. Metode yang dilakukan adalah dengan pemberian penyuluhan Perilaku Hidup Sehat Dan Bersih (PHBS) serta Gerakan Masyarakat Hidup Sehat (GERMAS) pada lanjut usia di Posyandu Lansia Puskesmas Sapta Taruna Kec. Bukit Raya-Kota Pekanbaru dengan menerapkan protokol kesehatan dalam berkumpul dengan metode 3M (memakai masker, mencuci tangan pakai sabun dan menjaga jarak).

Lokasi kegiatan pengabdian masyarakat dilaksanakan di Posyandu Lansia Puskesmas Sapta Taruna Kec. Bukit Raya-Kota Pekanbaru pada tanggal 11 Juni 2020. Sasaran pengabdian adalah sebanyak lebih kurang 25 orang lansia anggota posyandu yang juga merupakan jamaah majelis taklim Mesjid Nurul Muttaqin RT.10 Tangkerang Labuai Kota Pekanbaru.

Metode pendidikan masyarakat dengan cara sosialisasi langsung ke posyandu lansia ini dimulai dari tahap persiapan, pelaksanaan, observasi serta evaluasi sebagai berikut:

1. Tahap persiapan. Bekerjasama dengan kader lansia Puskesmas Sapta Taruna Pekanbaru untuk pelaksanaan pengabdian masyarakat dengan metode penyuluhan dalam rangka memberi pengetahuan kepada lansia perlunya menjaga kesehatan dan kebersihan selama pandemi COVID 19 dan menyambut New Normal.

2. Tahap pelaksanaan dengan beberapa tahap sebagai berikut:

a. pengisian biodata, pemeriksaan tekanan darah serta pengukurang berat badan.

b. membagikan kusioner PHBS dan GERMAS untuk evaluasi pre dan post. 

(GERMAS) kepada Lanjut Usia (LANSIA) Menghadapi Masa Pandemi Covid 19 dan New Normal dengan Metode 3M - Herniwanti, Octavia Dewi, Jasrida Yunita, Endang Purnawati Rahayu DOI : https://doi.org/10.31004/abdidas.v1i5.82

c. membagikan masker untuk menjaga protokol kesehatan di New Normal yang merupakan bagian dari metode $3 \mathrm{M}$.

d. Memberikan snack (makanan sehat)

e. memberikan sosialisasi dengan ceramah dan pemutaran video mengenai PHBS dan GERMAS

f. memberikan souvenir yang bermanfaat untuk membantu menjaga kebersihan selama masa pandemik COVID 19.

3. Tahap observasi dan evaluasi. Observasi dilakukan untuk mengetahui pengetahuan lansia terhadap materi yang telah disampaikan dengan memberikan kusioner secara tulisan dan juga tanya jawab secara lisan mengenai pemahaman PHBS dan GERMAS serta evaluasi langsung setelah kegiatan dilaksanakan.

\section{HASIL DAN PEMBAHASAN}

Pengabdian masyarakat dengan penyuluhan PHBS dan GERMAS pada lanjut usia di Posyandu Sapta Taruna Kota Pekanbaru dilaksanankan di Mesjid Nurul Muttaqien pada jam 09.00 - 11.30 WIB pada hari Sabtu, 11 Juli 2020. dihadiri oleh 15 orang lansia yang terdiri dari 13 orang wanita dan 2 orang pria dari jumlah anggota lansia sebanyak 25 orang.

Acara sosialisasi ini didampingi oleh kader posyandu sebanyak 5 orang dan 5 orang dosen Magister IKM Stikes Hang Tuah Pekanbaru yang menjadi pembicara merangkap panitia.
Semua peserta dalam acara ini diwajibkan memakai masker dan mencuci tangan sampai bersih di kran air masjid dan menjaga jarak selama acara berlangsung.

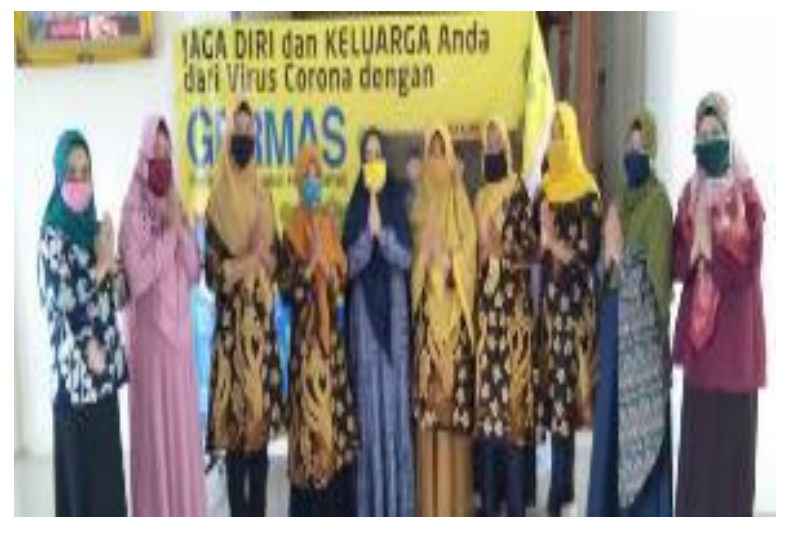

Gambar 1. Foto Bersama Panitia, Tim Pengabdian dan Kader Posyandu Lansia Puskesmas Sapta Taruna Pekanbaru.

Pengabdian masyarakat dari Prodi Magister ini merupakan kegiatan rutin setiap semesternya dan pada kesempatan ini dengan tema: "Lansia Aktif dan Sehat Menghadapi Masa New Normal”.

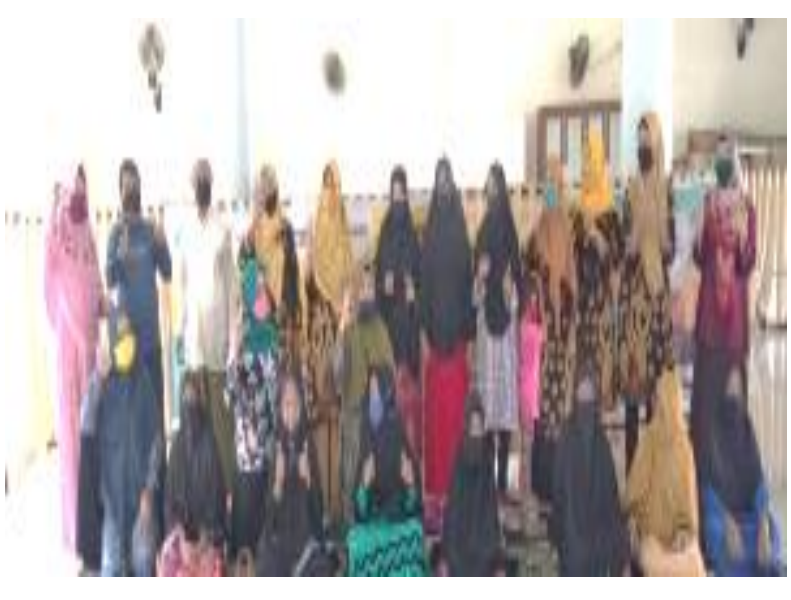

Gambar 2. Foto Bersama Peserta Lansia, Kader dan Panita

GERMAS dan PHBS adalah sebuah gerakan yang bertujuan untuk memasyarakatkan budaya 

(GERMAS) kepada Lanjut Usia (LANSIA) Menghadapi Masa Pandemi Covid 19 dan New Normal dengan Metode 3M - Herniwanti, Octavia Dewi, Jasrida Yunita, Endang Purnawati Rahayu DOI : https://doi.org/10.31004/abdidas.v1i5.82

hidup sehat serta meninggalkan kebiasaan dan perilaku masyarakat yang kurang sehat. Hal ini sangat diperlukan dalam masa pandemi COVID 19 ini terutama untuk lansia yang rentan terhadap penyakit ini (Tursina, 2020).

Metode pelaksanaan kegiatan ini diawali dengan pendampingan para lanjut usia untuk hadir di kegiatan ini yang diundang oleh para kader lansia, kemudian penyampaian pengetahuan menggunakan slide mengenai PHBS dan GERMAS dalam rangka menghindari infeksi corona virus dan diakhiri dengan sesi tanya jawab mengenai pola hidup bersih dan sehat. Kegiatan serupa mengenai promosi kesehatan pada lansia pada masa pandemi COVID 19 ini juga dilaksanakan di rumah panti jompo di Aceh oleh fakultas kedokteran Syiah Kuala yang memberikan penyuluhan pencegahan terjadinya infeksi corona virus yang menjadi epidemi global saat ini sehingga meningkatkan kewaspadaan terhadap bahaya penyebaran infeksi virus corona ini (Yanti et al., 2020).

Hasil dan dokumentasi pengabdian masyarakat di Posyandu Lansia Sapta Taruna Pekanbaru sebagai berikut :

1. Biodata dan pengukuran berat badan dan tekanan darah dari lansia yang hadir

Dari Biodata yang diisi oleh lansia yang hadir didapatkan informasi bahwa:

a. Usia lansia yang paling muda adalah 57 tahun serta yang paling tua adalah 89 tahun dan rata-rata usia 67 tahun. b. Berat badan rata-rata $58 \mathrm{~kg}$, yang paling kurus $36 \mathrm{~kg}$ dan paling berat $78 \mathrm{~kg}$.

c. Tensi rata-rata di 110/70 - 140/80 $\mathrm{mmHg}$.

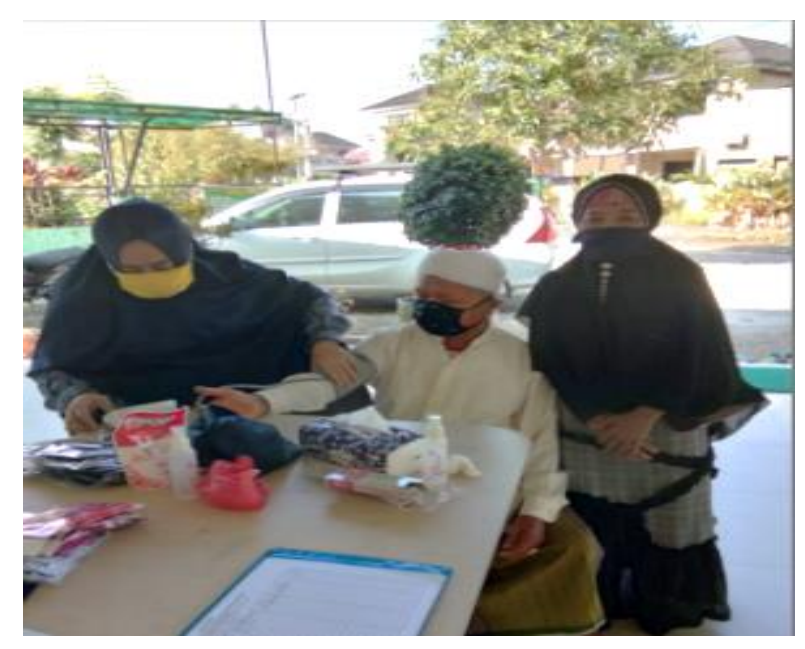

Gambar 3. Pengambilan Bidoata Lansia serta Pengukuran Tekanan Darah, Pembagian Masker dan Pengukuran Berat Badan.

2. Pembagian snack makanan sehat untuk lansia yang terdiri dari buah, telur rebus dan puding.

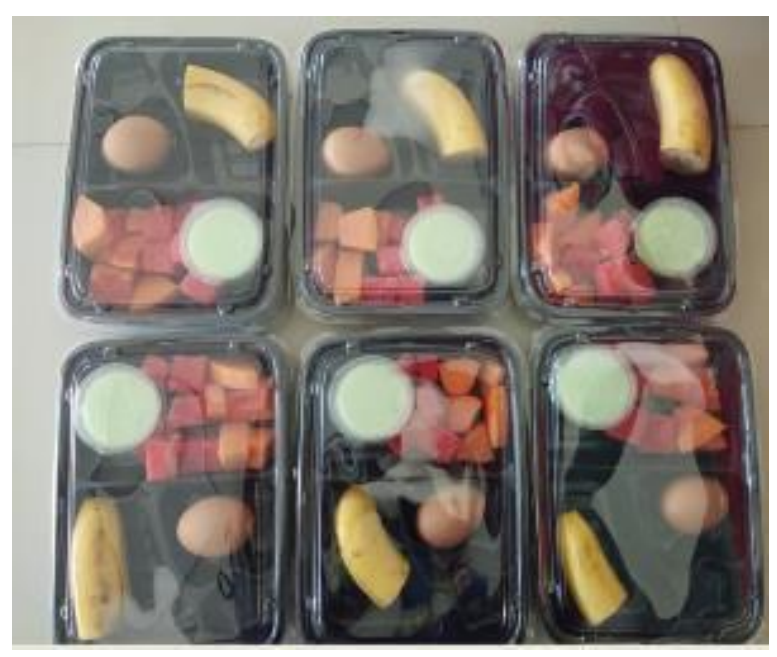

Gambar 4. Dokumentasi Menu snack/makanan sehat tambahan untuk Lansia.

3. Penyuluhan dan sosialisasi Gerakan Masyarakat Hidup Sehat ( GERMAS) dan 

dengan Metode 3M - Herniwanti, Octavia Dewi, Jasrida Yunita, Endang Purnawati Rahayu

PHBS (Perilaku Hidup Bersih dan Sehat) di masa New Normal.

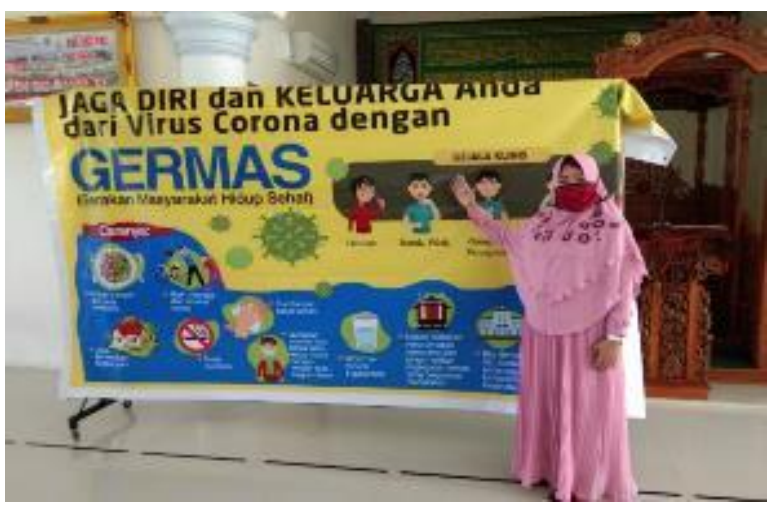

Gambar 5. Presentasi PHBS dan GERMAS

Dengan adanya penyuluhan maka diharapkan akan ada kesadaran untuk menjaga kebersihan diri dan juga mengikuti protokol kesehatan selama COVID 19 yaitu 3M (memakai masker, menjaga jarak, mencuci tangan sampai bersih. Karena dengan adanya kesadaran maka perubahan perilaku lansia menjadi sebuah perilaku yang lebih baik dan sehat, sangat penting dan bermanfaat untuk mencegah penyakit, kesejahteraan dan kualitas hidup mereka (Fried et al., 2013).

Dengan adanya penyuluhan ini diharapkan Lansia yang berperilaku kurang sehat bisa dikurangi karena menurut penelitian masih ada sejumlah lansia yang berperilaku tidak sehat sebanyak 23\% (Kustantya, 2013). Karena usia karakteristik individu dari lansia sulit untuk diubah (Azwar, 2013) termasuk diantaranya mengenai kebiasaan hidup bersih dan sehat oleh karena itu dibutuhkan dukungan dari lingkungan dan keluarga agar lansia tetap bisa menjaga kebersihan diri selama pandemi COVID 19 dan era New Normal ini agar tidak tertular terutama rentan yang mempunyai penyakit bawaan.

4. Pemberian souvenir yang terdiri dari peralatan kebersihan pribadi (sabun anti bakteri dan handuk kecil) untuk membiasakan cuci tangan pakai sabun serta menjaga kebersihan lansia.

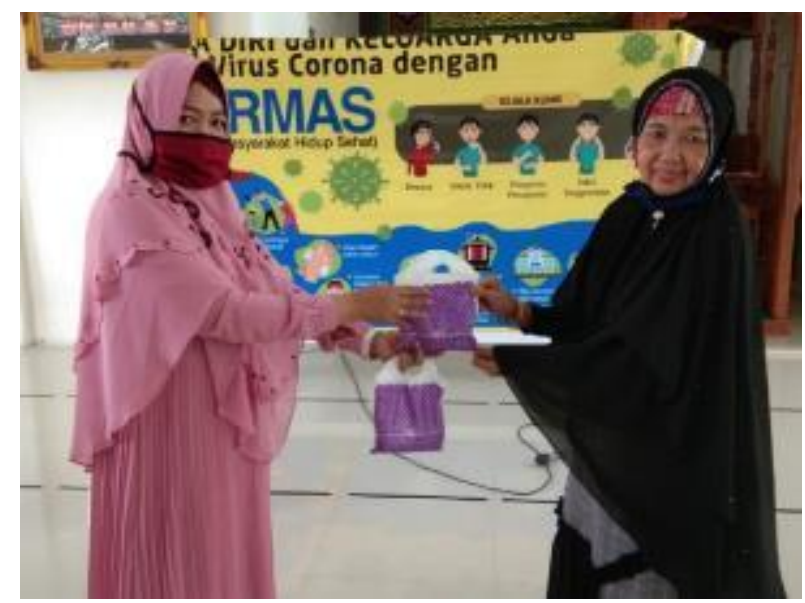

Gambar 6. Pemberikan Souvenir kebersihan pribadi kepada perwakilan Lansia.

5. Hasil evaluasi dan observasi dari kegiatan pengabdian ini memperlihatkan pengetahuan lansia mengenai program pemerintah untuk lansia seperti hari Lansia Nasional dan kegiatan PHBS dan GERMAS masih kurang paham walau secara kegiatan sebagian sudah dilaksanakan dalam aktifitas sehari-hari, seperti cuci tangan sampai bersih dan mengikuti protokol COVID 19 bahwa tidak boleh pulang kampung/mudik selama masa PSPB (Pembatasan Sosial Berskala Besar) dan selalu menjaga kebersihan masjid sebagai tempat ibadah bersama dengan membawa alat 

(GERMAS) kepada Lanjut Usia (LANSIA) Menghadapi Masa Pandemi Covid 19 dan New Normal dengan Metode 3M - Herniwanti, Octavia Dewi, Jasrida Yunita, Endang Purnawati Rahayu

DOI : https://doi.org/10.31004/abdidas.v1i5.82

sholat sendiri dari rumah dan menjaga jarak selama beribadah dan memakai masker.

Minat lansia ke posyandu masih kurang terutama lansia lelaki dilihat dari sedikitnya peserta lansia pria $2(13 \%)$ orang dari 15 orang peserta yang hadir. Peserta lansia rata-rata berstatus janda (80\%) dan kemungkinan mempunyai banyak waktu luang untuk hadir dalam acara sosialisasi dan kegiatan yang diadakan oleh Posnyandu Lansia. Walaupun di Posyandu Lansia banyak terdapat informasi dari Dinas Kesehatan dan juga program pemerintah yang bertujuan untuk meningkatkan pengetahuan kesehatan dan kesejahteraan lansia dan biasanya dekat dengan rumah mereka tapi masih kurangnya kehadiran disebabkan oleh kurnangya promosi kesehatan oleh kader lansia dan dukungan dari keluarga. Hal ini juga ditemukan dalam penelitian (Ningsih, 2014), bahwa tidak ada hubungan antara jarak tempat tinggal dengan kehadiran lansia di posyandu (Yuliana, 2015). Jadi dari evalusi ini disimpulkan diperlukan dukungan keluarga untuk lansia mau bersosialisasi dan meningkatkan pengetahuan tentang kesehatan dan kesejahteraan mereka.

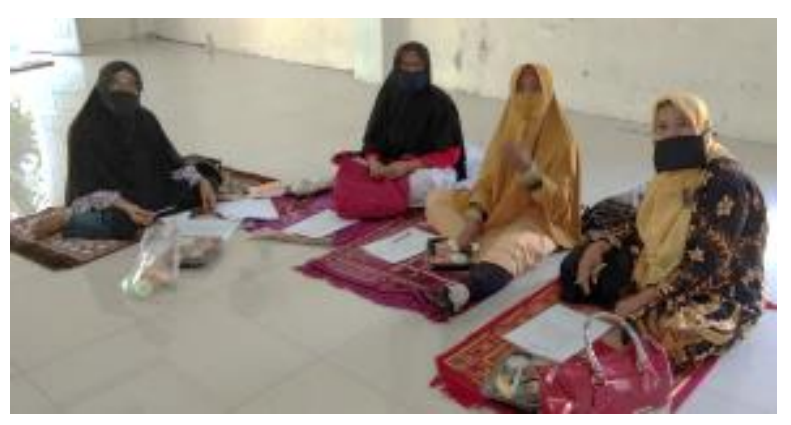

Gambar 7: Para peserta Lansia mengisi Kuisioner PHBS dan GERMAS sebelum acara berlangsung

Pada kesempatan yang sama, tokoh masyarakat setempat yang juga ketua Dewan Mesjid Nurul Muttaqin Sidi Ali Zaman (73 tahun) dalam kata sambutannya mengucapkan syukur dan mengapresiasi kegiatan yang dilakukan oleh Dosen Magister STIKES Hang Tuah Pekanbaruk, karena merasa senang sekali dengan ilmu yang telah diberikan dan berharap semoga manfaat untuk semua peserta yang hadir.

Paparan tentang kesehatan dan perilaku hidup sehat dan bersih ini membuat para Lansia tertarik karena promosi kesehatan di bidang kesehatan lingkungan terutama dalam masa covid 19 dan era new normal ini sangat diperlukan kaerna dapat meningkatkan pengetahuan tentang Perilaku Hidup Bersih dan Sehat (GERMAS). Promosi kesehatan secara terus menerus terutama pada Lansia dapat memberikan pengaruh terhadap pengetahuan dan sikap PHBS (Kurniawan et al., 2019) dan (R Roni, S Susmini, 2018).

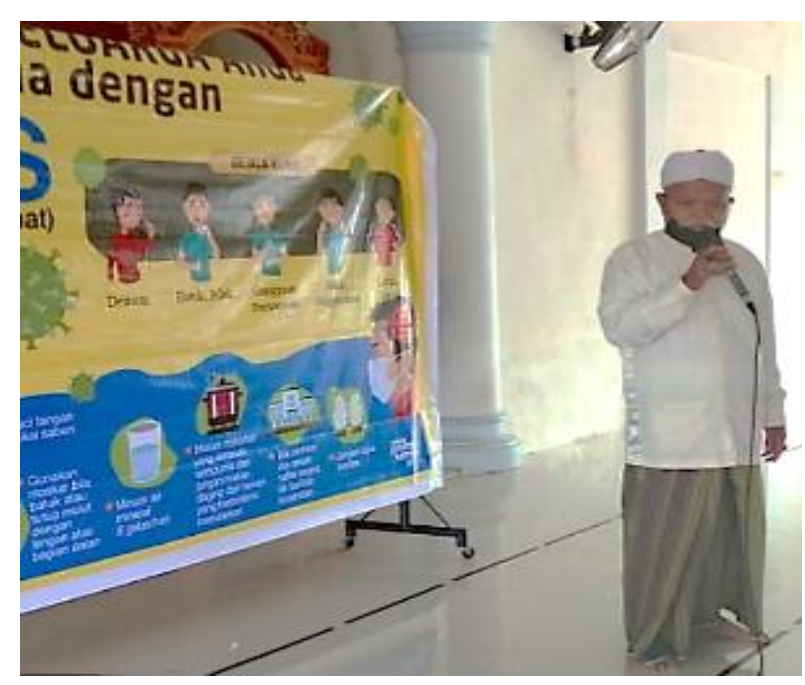



dengan Metode 3M - Herniwanti, Octavia Dewi, Jasrida Yunita, Endang Purnawati Rahayu DOI : https://doi.org/10.31004/abdidas.v1i5.82

Gambar 8: Kata sambutan Ketua Dewan Mesjid Nurul Muttaqin

Pernyataan ini sesuai dengan sambutan yang baik dari pihak pengurus panti jompo pada kegiatan pengabdian masyarakat kepada Lansia di yang dilaksanakan oleh tim dosen Stikes Hang Tuah Pekanbaru di UPT Pelayanan Sosial Tresna Werdha Husnul Khotimah Kota Pekanbaru pada bulan Januari 2020 lalu dimana sambutan dari pengurus sangat berterima kasih karena ada kepedulian dari akademis untuk memberikan ilmu dan sosialisasi tentang kebersihan diri kepada lansia dan dukungan dari pengurus panti jompo sangat mendukung untuk lansia mau bersosialisasi dan menambah ilmu pengetahuan mengenai kesehatan dan menjaga kebersihan diri dan lingkungan (Herniwanti et al., 2020).

\section{SIMPULAN}

Pengadiman masyarakat dengan Tema “ Lansia Aktif dan Sehat Menghadapi Masa New Normal " dengan sub tema PHBS \& GERMAS (Perilaku Hidup Sehat Dan Bersih \& Gerakan Masyarakat Hidup Sehat) kepada LANSIA di Posyandu Lansia Tangkerang Labuai Puskesmas Sapta Taruna Kec. Bukit Raya, Kota Pekanbaru berjalan dengan baik dan lancar walaupun dimasa wabah pandemic covid 19 dan era new normal dengan menerapkan protokol kesehatan 3M selama acara berlansung.

Selanjutnya para Lansia dan Kader berharap pada STIKES Hang Tuah, agar kegiatan yang bermanfaat ini digelar regular atau sesering mungkin didaerah ini, mungkin untuk nanti bisa ada latihan-latihan tentang kesehatan yang lebih spesifik dengan memberikan thema yang lain.

Hasil evaluasi dan observasi pemahaman PHBS dan GERMAS pada lansia menunjukkan masih kurang dikenal dan diperlukan promosi kesehatan mengenai program pemerintah untuk lansia, baik untuk kesehatan maupun yang berhubungan dengan kesehatan lingkungan. Lansia memerlukan dukungan dari keluarga dan masyarakat untuk memberikan sosialisasi mengenai kesehatan dan kebersihan terutama dalam masa COVID 19 dan New Normal ini.

Pernyataan dari Ketua Prodi Magister STIKES Hang Tuah. Dr. Mitra. SKM. M.Kes yang menyebutkan kegiatan pengabdian masyarakat dalam masa pandemi COVID 19 dan New Normal yang dilakukan oleh Dosen Magister STIKES Hang Tuah tersebut, merupakan salah satu bentuk pelaksanaan Tri Darma Perguruan Tinggi yang memberikan pendidikan pada masyarakat. Menurutnya, pengabdian masyarakat itu, yang terpenting adalah sasarannya tepat di masyarakat dan pengabdian itu benar-benar mampu membawa dampak baik dan pengaruh positif di masyarakat.

\section{UCAPAN TERIMA KASIH}

Terimakasih diucapkan kepada Kader Lansia Posyandu Lansia Tangkerang Labuai Puskesmas Sapta Taruna Kec. Bukit Raya, Kota Pekanbaru serta pengurus Mesjid Nurul Muttaqin yang telah memberi kesempatan sehingga acara bisa berjalan dengan lancar dan juga kepada Ketua 

(GERMAS) kepada Lanjut Usia (LANSIA) Menghadapi Masa Pandemi Covid 19 dan New Normal dengan Metode 3M - Herniwanti, Octavia Dewi, Jasrida Yunita, Endang Purnawati Rahayu DOI : https://doi.org/10.31004/abdidas.v1i5.82

Yayasan dan Pimpinan serta LPPM STIKes Hang Tuah Pekanbaru yang telah mendukung baik secara moril dan materil untuk pelaksanaan acara pengabdian masyarakat kepada dosen Magister Ilmu Kesehatan Masyarakat STIKes Hang Tuah Pekanbaru dalam rangka pelaksaan Tridarma Perguruan Tinggi dalam bidang pengabdian masyarakat. Semoga kegiatan ini tetap berlanjut.

\section{DAFTAR PUSTAKA}

Arpan, I., \& Sunarti, S. (2017). Faktor Frekuensi Kunjungan Lansia Ke Posyandu Lansia Di Kecamatan Pontianak Timur. Jurnal Vokasi Kesehatan, 3(2), 92. https://doi.org/10.30602/jvk.v3i2.108

Azwar, S. (2013). Sikap Manusia dan Pengukurannya. Pusat Belajar OffsetJogjakarta.

Fried, L. P., Carlson, M. C., McGill, S., Seeman, T., Xue, Q.-L., Frick, K., Tan, E., Tanner, E. K., Barron, J., Frangakis, C., Piferi, R., Martinez, I., Gruenewald, T., Martin, B. K., Berry-Vaughn, L., Stewart, J., Dickersin, K., Willging, P. R., \& Rebok, G. W. (2013). Experience Corps: A dual trial to promote the health of older adults and children's academic success. Contemporary Clinical Trials, 36(1), 1-13. https://doi.org/https://doi.org/10.1016/j.cct.20 13.05.003

Herman. (2011). Hubungan Antara Pengetahuan Dan Sikap Lansia Serta Peran Kader Posyandu Dengan Perilaku Pemanfaatan Posyandu Lansia Di Kelurahan Kedamin Hulu Kecamatan Putussibau Selatan Kabupaten Kapuas Hulu.

Herniwanti, H., Yunita, J., Rahayu, E. P., \& Kiswanto, K. (2020). Penyuluhan Personal Higyene pada Lanjut Usia di UPT Pelayanan Sosial Tresna Werdha Husnul Khotimah Kota Pekanbaru. Jurnal Abdidas, 1(4 SE-),
254-260.

https://doi.org/10.31004/abdidas.v1i4.55

Juniardi, F. (2013). Faktor-faktor yang Mempengaruhi Rendahnya Kunjungan Lansia ke Posyandu Lansia di Puskesmas Batang Beruh Kecamatan Sidikalang Kabupaten Dairi. Welfare State, 2(1). https://media.neliti.com/media/publications/2 21988-faktor-faktor-yang-mempengaruhirendahny.pdf

Kauman, P., Wijirejo, D., Wahyuningsih, I., Wahyuningtyas, W., Sari, D., Widyastuti, O., Dahlan, U. A., \& Prof, J. (2019). Pendampingan gerakan masyarakat hidup sehat Di Padukuhan Kauman, Bajang, Ngeblak, Desa Wijirejo, Pandak, Bantul. $3(1), 61-72$.

Kurniawan, A., Putri, R. M., \& Widiani, E. (2019). Pengaruh Promosi Kesehatan Terhadap Pengetahuan Dan Sikap Tentang Perilaku Hidup Bersih dan Sehat Kelas IV dan V Sekolah Dasar. Journal Nursing News, 4(1), 100-111.

https://doi.org/10.1021/BC049898Y

Kustantya, N. (2013). Hubungan Tingkat Pengetahuan Dengan Perilaku Hidup Bersih dan Sehat (PHBS) Pada Lansia. Jurnal Keperawatan, 4(1), 31-33. https://doi.org/10.22219/jk.v4i1.2378

Ningsih, R. (2014). Faktor-faktor yang Mempengaruhi Minat Lansiamengunjungi Posyandu Lansia. Jurnal Online Mahasiswa Program Studi Ilmu Keperawatan Universitas Riau, 1(2), 1-10. https://media.neliti.com/media/publications/1 83825-ID-faktor-faktor-yang-mempengaruhiminat-la.pdf

Putri, R. M. (2019). VISIKES : Jurnal Kesehatan Masyarakat. VISIKES, 120-129.

R Roni, S Susmini, R. P. (2018). Peran Promosi Kesehatan Phbs Terhadap Pengetahuan Dan Sikap Remaja Dalam Pencegahan Diare. Nursing News : Jurnal Ilmiah Keperawatan, $3(3)$. 
372 Penyuluhan Perilaku Hidup Sehat dan Bersih (PHBS) dan Gerakan Masyarakat Hidup Sehat (GERMAS) kepada Lanjut Usia (LANSIA) Menghadapi Masa Pandemi Covid 19 dan New Normal dengan Metode 3M - Herniwanti, Octavia Dewi, Jasrida Yunita, Endang Purnawati Rahayu DOI : https://doi.org/10.31004/abdidas.v1i5.82

https://publikasi.unitri.ac.id/index.php/fikes/a rticle/view/1312

Tursina, A. (2020). Bunga Rampai Artikel Penyakit Virus Korona ( COVID-19) Editor: Titik Respati. Kopidpedia, 203-215. http://repository.unisba.ac.id

Yanti, B., Priyanto, H., \& Zulfikar, T. (2020). Sosialisasi Waspada Infeksi Corona Viru Pada Lansia di Panti Jompo Rumoh Seujahtra. MARTABE Jurnal Pengabdian Masyarakat, 3(1), 67-72.

Yuliana. (2015). Hubungan Dukungan Keluarga Dengan Kepatuhan Pembatasan Cairan Pada Pasien Gagal Ginjal Kronik Dengan Terapi Hemodialisis Di Rs Pku Muhammadiyah Yogyakarta. Sekolah Tinggi Ilmu Kesehatan 'Aisyiyah Yogyakarta. 